\title{
Pengaruh Kompetensi Pedagogik Dan Motivasi Kerja Terhadap Kinerja Guru SMP Negeri 17 - Kota Tangerang Selatan
}

\author{
Suprianto \\ Dosen Fakultas Ekonomi, Universitas Pamulang \\ Email : antochbsd@yahoo.com
}

\begin{abstract}
ABSTRAK
Penelitian ini bertujuan untuk mengetahui pengaruh antara kemampuan pedagogik guru dan motivasi kerja guru terhadap kinerja guru SMP Negeri 17 Kota Tangerang Selatan. Metode penelitian yang digunakan adalah metode survei dengan responden 32 dari 42 guru SMP Negeri 17 Kota Tangerang Selatan.

Teknik pengumpulan data menggunakan instrumen yang berbentuk angket untuk variabel kemampuan pedagogik guru dan motivasi kerja guru. Sedangkan untuk variabel kinerja guru, data diperoleh dari penilaian DP3 guru PNS SMP Negeri 17 Kota Tangerang Selatan pada tahun 2010. Instrumen penelitian dikalibrasi dengan menggunakan uji validitas dan uji reliabilitas. Uji validitas dilakukan dengan menggunakan uji korelasi Product Moment Pearson, sedangkan uji reliabilitas dilakukan dengan menggunakan rumus Alpha.

Teknik analisis data yang digunakan analisis deskriptif dan analisis verifikatif yang meliputi Uji Instrumen, Uji Prasyarat Analisis dan Uji Statistik.

Hasil pengujian dan analisisnya adalah sebagai berikut:

1. Tidak terdapat pengaruh yang signifikan antara kompetansi pedagogik $\left(\mathrm{X}_{1}\right)$ terhadap kinerja guru (Y) walaupun memiliki persamaan regresi $\mathrm{Y}=527,052+$ $0,320 \mathrm{X}_{1}$, dan terdapat korelasi yang lemah positif sebesar 0,171 . Uji hipotesis dengan $\rho$ value $0,350>0,05$.

2. Terdapat pengaruh yang signifikan antara motivasi kerja guru $\left(X_{2}\right)$ terhadap kinerja guru $(\mathrm{Y})$ ditunjukkan oleh persasmaan regresi $\mathrm{Y}=639,925-0,579 \mathrm{X}_{2}$ dan terdapat korelasi yang cukup kuat negative sebesar $-0,355$. Uji hipotesis dengan $\rho$ value $0,046<0,05$.

3. Terdapat pengaruh yang signifikan antara kompetensi pedagogik guru $\left(\mathrm{X}_{1}\right)$ dan motivasi kerja $\left(\mathrm{X}_{2}\right)$ secara bersama-sama terhadap kinerja guru $(\mathrm{Y})$ ditunjukkan oleh persamaan regresi $\mathrm{Y}=605,761+0,678 \mathrm{X}_{1}-0,832 \mathrm{X}_{2}$ dan terdapat korelasi cukup kuat positif sebesar 0,285. Uji hipotesis dengan $\rho$ value $0,026<0,05$. Konstibusi kompetensi pedagogik dan motivasi kerja dapat menafsirkan variansi kinerja guru sebesar 23,8\%.
\end{abstract}

\section{Kata Kunci: Kemampuan Pedagogik, Motivasi Kerja, Kinerja Guru}




\section{PENDAHULUAN}

\section{A. Latar Belakang Masalah}

Sekolah

merupakan

lembaga yang bersifat kompleks dan unik, yaitu di dalamnya terdapat berbagai dimensi yang berkaitan satu dengan lainnya dan saling menentukan. Selain itu sekolah juga memiliki ciri-ciri khusus yang tidak dimiliki oleh lembaga lain. Ciri-ciri yang menempatkan sekolah memiliki karakter tersendiri yaitu bahwa di sekolah terjadi proses pembelajaran dan tempat terselenggaranya pembudayaan kehidupan umat manusia. Oleh karena itu sebagai organisasi, sekolah memerlukan tingkat koordinasi yang tinggi antar personilnya, baik itu unsur kepala sekolah dengan tenaga pendidik (guru) dan karyawan sekolah, maupun guru dengan karyawan.

Menurut Undang-Undang Republik Indonesia no. 20 (2003: 25) tentang Sistem Pendidikan Nasional, "Pendidik merupakan tenaga profesional yang bertugas merencanakan dan melaksanakan proses pembelajaran, menilai hasil pembelajaran, melakukan pembimbingan dan pelatihan, ...”. Untuk dapat melaksanakan tugas dan tanggungjawab tersebut guru bekerjasama dengan orang tua dan masyarakat. Selain itu seorang guru dituntut memiliki beberapa kemampuan dan keterampilan tertentu sebagai bagian dari kompetensi profesionalismenya. Kompetensi merupakan suatu kemampuan yang mutlak dimiliki oleh guru agar tugasnya sebagai pendidik dapat terlaksana dengan baik.
Tugas guru erat kaitannya dengan peningkatan sumber daya manusia, oleh karena itu perlu upaya-upaya untuk meningkatkan mutu guru untuk menjadi tenaga profesional. Agar peningkatan mutu pendidikan dapat berhasil. Sebagaimana yang dikemukakan oleh Tilaar : "Peningkatan kualitas pendidikan tergantung banyak hal, terutama mutu gurunya" (H.A.R, 1999: 104).

Profesional tenaga pendidik sangat erat keterkaitannya dengan peningkatan sumber daya manusia melalui sektor pendidikan. Oleh karena itu pemerintah melalui Departemen Pendidikan Nasional terus menerus berupaya melakukan berbagai perubahan dan pembaharuan sistem pendidikan. Salah satu upaya yang sudah dan sedang dilakukan pemerintah yaitu berkaitan dengan faktor peningkatan kompetensi dan kesejahteraan guru. Dengan upaya tersebut diharapkan dapat meningkatkan mutu pendidikan nasional, sehingga tujuan pembangunan nasional dalam bidang pendidikan yaitu untuk mencerdaskan kehidupan bangsa dan meningkatkan kualitas manusia Indonesia yang beriman, bertakwa, dan berakhlak mulia serta menguasai ilmu pengetahuan, teknologi, dan seni dalam mewujudkan masyarakat yang maju, adil, makmur, dan beradab berdasarkan Pancasila dan Undang-Undang Dasar Negara Republik Indonesia Tahun 1945 dapat tercapai.

Untuk menjadikan guru sebagai tenaga profesional maka perlu diadakan pembinaan secara 
terus menerus dan berkesinambungan, selain itu guru sebagai tenaga kerja perlu diperhatikan, dihargai dan diakui keprofesionalannya. Dengan demikian pekerjaan sebagai guru bukan semata-mata pekerjaan pengabdian, namun guru merupakan pekerja profesional seperti halnya pekerja lainnya seperti: arsitek, akuntan, pengacara, pengusaha, dokter dan sebagainya.

Sebagai tenaga profesional pada jalur pendidikan formal yang diangkat sesuai dengan peraturan perundang-undangan, guru wajib memiliki kualifikasi akademik, kompetensi, sertifikat pendidik, sehat jasmani dan rohani, serta memiliki kemampuan untuk mewujudkan tujuan pendidikan nasional. Oleh karena itu, usahausaha yang dapat dilakukan untuk meningkatkan profesionalisme guru dalam peningkatan kompetensinya dapat ditempuh melalui kegiatan penataran, pelatihan maupun kesempatan untuk belajar lagi. Ruang lingkup peningkatan kompetensi guru meliputi peningkatan : 1) Kompetensi pedagogik, 2) Kompetensi kepribadian, 3) Kompetensi profesional, dan 4) Kompetensi sosial.

Motivasi kerja sangatlah diperlukan guru dalam rangka peningkatkan kompetensi dan keberhasilan dalam proses belajar mengajar. Motivasi kerja merupakan unsur psikologis yang harus dimiliki guru. Guru yang tidak punya motivasi mengajar yang baik tidak akan berhasil dalam proses belajar mengajarnya, karena yang dilakukannya tidak dikarenakan kecintaan terhadap dunia kerjanya melainkan karena keterpaksaan. Keberhasilan guru dalam mengajar dikarenakan dorongan/ motivasi kerja merupakan pertanda bahwa apa yang telah dilakukan oleh guru telah sesuai dengan kebutuhannya.

\section{B. Tujuan Penelitian}

1. Untuk mengetahui pengaruh secara parsial antara kompetensi pedagogik terhadap kinerja guru SMP Negeri 17 Kota Tangerang Selatan.

2. Untuk mengetahui pengaruh secara parsial antara motivasi kerja terhadap kinerja guru SMP Negeri 17 Kota Tangerang Selatan.

3. Untuk mengetahui seberapa besar pengaruh secara simultan antara kompetensi pedagogik dan motivasi kerja guru secara bersama-sama terhadap guru pada SMP Negeri 17 Kota Tangerang Selatan.

\section{TINJAUAN PUSTAKA}

\section{A. Kompetensi Pedagogik}

Kompetensi atau kemampuan didefinisikan sebagai suatu sifat dasar seseorang yang dengan sendirinya berkaitan dengan pelaksanaan suatu pekerjaan secara efektif atau sangat berhasil. Ketidaksamaan dalam kompetensi inilah yang membedakan seseorang pelaku memiliki keunggulan dari pelaku yang lain. Selain itu kompetensi juga berarti kelompok keterampilan, perilaku, atau 
pengetahuan yang diidentifikasi sebagai standar kinerja untuk pekerjaan tertentu.

Dalam buku Pedagogik Teoritis Sistematis karya Tatang Syaripudin dan Kurniasih (2009), disampaikan bahwa pedagogik berasal dari bahasa Yunani Kuno, yaitu paedos (anak) dan agogos (mengantar, membimbing, memimpin). Dari dua istilah diatas timbul istilah baru yaitu paedagogos dan pedagog, keduanya memiliki pengertian yang hampir serupa, yaitu sebutan untuk pelayan pada zaman Yunani kuno yang mengantarkan atau membimbing anak dari rumah ke sekolah setelah sampai di sekolah anak dilepas. Inti dari pengertian pedagogik adalah mengantarkan anak menuju pada kedewasaan.

\section{Berkenaan}

dengan

kompetensi pedagogik, Haryanto (2010) menyatakan bahwa kompetensi pedagogik merupakan bagian yang tak terpisahkan dari empat kompetensi utama yang harus dimiliki seorang guru, yaitu kompetensi pedagogik, kepribadian, sosial, dan professional. Keempat kompetensi tersebut terintegrasi dalam kinerja guru saat melaksanakan profesinya. Kompetensi pedagogik merupakan kemampuan seorang guru dalam mengelola proses pembelajaran peserta didik. Selain itu kemampuan pedagogik juga ditunjukkan dalam membantu, membimbing dan memimpin peserta didik.

Kompetensi pedagogik guru dalam mengelola pembelajaran perlu mendapat perhatian yang serius (Mulyasa, 2006). Hal ini penting karena pendidikan di Indonesia dinyatakan kurang berhasil oleh sebagian masyarakat karena dinilai kering dari aspek pedagodik, dan sekolah lebih bersifat sebagai mekanis sehingga peserta didik cenderung kerdil karena tidak mempunyai dunianya sendiri.

Dalam penelitian ini, ruang lingkup kompetensi pedagogik guru berkenaan dengan kepiawaian pendidik dalam mengelola pembelajaran, indikator-indikator yang diteliti meliputi: 1) memahami wawasan atau landasan kependidikan, 2) memahami peserta didik, 3) pengembangan kurikulum dan silabus, 4) merancang pembelajaran, 5) pelaksanaan pembelajaran melibatkan dan menghargai siswa sebagai subyek, 6) penggunaan teknologi dalam belajar mengajar, 7) penilaian terhadap proses dan hasil belajar, serta 8) mendorong siswa agar mengembangkan dan meningkatkan berbagai potensi yang dimiliki.

\section{B. Motivasi Kerja Guru}

Motivasi berasal dari kata latin movere yang berarti dorongan atau menggerakkan. Motivasi (motivation) dalam manajemen hanya ditujukan pada sumber daya manusia umumnya dan bawahan khususnya. Motivasi mempersoalkan bagaimana caranya mengarahkan daya dan potensi bawahan, agar mau bekerja secara produktif berhasil mencapai dan 
wewujudkan tujuan yang telah ditentukan (Malayu Hasibuan, 1999: 131). Motif adalah apa yang menggerakkan seseorang untuk bertindak dengan cara tertentu atau sekurang-kurangnya mengembangkan suatu kecenderungan tertentu.

Malayu SP. Hasibuan mendefenisikan motivasi adalah pemberian daya penggerak yang menciptakan kegairahan kerja seseorang, agar mereka mau bekerja sama, efektif dan terintegrasi dengan segala upayanya untuk mencapai kepuasan. Sedang Gibson dkk, mendefinisikan motivasi adalah kekuatan yang mendorong seseorang karyawan yang menimbulkan dan mengarahkan perilaku (1996: 185).

Dalam penelitian ini, yang dimaksud dengan motivasi kerja guru adalah dorongan bagi seorang guru untuk melakukan pekerjaan agar tercapai tujuan pekerjaan sesuai dengan rencana. Pekerjaan guru dalam kegiatan belajar mengajar akan tercapai jika guru mempunyai motivasi yang kuat, sedang guru yang kurang termotivasi dalam bekerja maka keinginan/ minatnya pada pekerjaan akan kurang. Indikatorindikator yang digunakan untuk mengukur motivasi kerja guru meliputi :

1) Berusaha unggul

2) Menyelesaikan tugas dengan baik.

3) Rasional dalam meraih keberhasilan

4) Menyukai tantangan

5) Menerima tanggungjawab untuk sukses.
6) Menyukai situasi pekerjaan dengan tanggungjawab pribadi, umpan balik, dan resiko tingkat menengah.

\section{Kinerja Guru}

Kinerja

didefinisikan sebagai tingkat keberhasilan di dalam melaksanakan tugas serta kemampuan untuk mencapai tujuan yang telah ditetapkan (Donelly, Gibson and Ivanvevich, 1994: 328). Istilah kinerja bersinonim dengan: a) prestasi kerja; b) pelaksanaan kerja; c) pencapaian kerja; d) hasil kerja/unjuk kerja/penampilan kerja (Sedarmayanti, 2001:50). Whitmore menegaskan bahwa kinerja adalah suatu perbuatan, suatu prestasi, suatu pameran umum keterampilan (Whitmore, 1997: 104). Menurut Henderson dan Thomson, kinerja tergantung pada tiga elemen, yaitu: fokus, keinginan, dan kapabilitas. Kinerja berkorelasi dengan pemahaman, pengetahuan, kejelasan, kompetensi, kepercayaan, nilai, emosi, dan sikap (Henderson and Thomson, 2003: 51)

Penilaian terhadap kinerja meliputi aspek-aspek berikut ini: 1) Knowledge; pengetahuan; 2) Reasoning; aplikasi pengetahuan dalam berbagai konteks pemecahan masalah; 3) Skill; kecakapan dalam berbagai jenis keterampilan komunikasi, visual, karya seni, dan lain-lain; 4) Product; dan 5) Affect; berhubungan dengan perasaan, sikap, nilai, minat, motivasi (Stiggins, 1994: 171). Selanjutnya dikemukakan bahwa diantara kelima target tersebut, penilaian 
kinerja sangat efektif untuk menilai pencapaian target dari reasoning, skill dan karya cipta. Untuk dapat melakukan penilaian terhadap skill dan karya cipta guru, diperlukan alat ukur terhadap kinerja guru yang disebut dengan tes kinerja. Menurut Yacobs (1992:137), tes kinerja menyediakan cara mengukur skill dan kemampuan yang tidak dapat diukur dengan tes tertulis.

Dalam pedoman penilaian dinyatakan bahwa tes kinerja adalah tes yang penugasannya disampaikan dalam bentuk lisan atau tertulis dan proses penilaiannya dilakukan sejak melakukan persiapan, melaksanakan tugas sampai dengan hasil akhir (Depdikbud, 1994: 8). Sebagai alat penunjang dalam melaksanakan tes kinerja digunakan lembar observasi atau sebuah format pengamatan kinerja atau penampilan pekerja. Dalam lembar pengamatan tertera aspek-aspek yang diamati sesuai dengan target pembelajarannya. Berdasarkan deskripsi yang nampak selama proses pengamatan, ditentukanlah skor kinerja dengan berpedoman pada kriteria penilaian yang telah ditetapkan sebelumnya.

Agar tercapai penilaian kinerja yang sesuai dengan keadaan sebenarnya (reliable), diperlukan upaya untuk meminimalkan adanya faktor penyebab perbedaan keputusan penskoran terhadap kinerja yang sama. Reliabilitas (konsistensi) dalam penskoran sangat dituntut demi keadilan bagi peserta didik.
Upaya-upaya yang dapat dilakukan antara lain penetapan kriteria yang jelas, pemahaman yang seragam dari sejumlah penilai terhadap kriteria, proses pengukuran tidak hanya dilakukan oleh satu orang, tidak menangguhkan penilaian, serta dilakukan secara berulang terhadap pemahaman kriteria (Herman, 1992).

Selain pengukuran yang konsisten, diperlukan juga alat ukur yang sahih (valid). Validitas (kesahihan) alat ukur berkaitan dengan kesesuaian antara alat ukur dengan aspek-aspek yang hendak diukur. Menurut Wayan Nurkancana (1986:127) alat ukur dapat dikatakan sahih apabila alat ukur tersebut dapat mengukur dengan tepat apa yang hendak diukur.

Untuk penilaian kinerja guru (pegawai negeri sipil), pemerintah telah menyusun standart penilaian yang tercantum dalam Daftar Penilaian Pelaksanaan Pekerjaan (DP3). DP3 adalah suatu daftar yang memuat hasil penilaian pelaksanaan pekerjaan seorang Pegawai Negeri Sipil dalam jangka waktu 1 (satu) tahun yang dibuat oleh Pejabat Penilai (Bayu, N., 2011). Pejabat Penilai merupakan atasan langsung Pegawai Negeri Sipil yang dinilai, dengan ketentuan serendah-rendahnya kepala urusan atau pejabat lain yang setingkat dengan itu.

Dalam penelitian ini, yang dimaksud dengan kinerja guru meliputi unsur-unsur kinerja yang tercantum dalam Daftar Penilaian 
Pelaksanaan Pekerjaan $\left(\mathrm{DP}_{3}\right)$ yang dikeluarkan oleh kepala SMPN 17 Kota Tangerang Selatan, meliputi:

1) Kesetiaan, yaitu tekad dan kesanggupan mentaati, melaksanakan, dan mengamalkan sesuatu yang disertai dengan penuh kesadaran dan tanggungjawab. Tekad dan kesanggupan tersebut harus dibuktikan dalam sikap dan tingkah laku sehari-hari serta dalam perbuatan dalam melaksanakan tugas;

2) Prestasi kerja, merupakan hasil kerja yang dicapai oleh seorang Pegawai Negeri Sipil dalam melaksanakan tugas yang dibebankan kepadanya;

3) Tanggung jawab, merupakan kesanggupan seorang Pegawai Negeri Sipil menyelesaikan pekerjaan yang diserahkan kepadanya dengan sebaik-baiknya dan tepat pada waktunya serta berani memikul risiko atas keputusan yang diambilnya atau tindakan yang dilakukannya;

4) Ketaatan, Kesanggupan seorang Pegawai Negeri Sipil,untuk mentaati segala peraturan perundangundangan dan peraturan kedinasan yang berlaku, mentaati perintah kedinasan yang diberikan oleh atasan yang berwenang, serta kesanggupan untuk tidak melanggar larangan yang ditentukan;

5) Kejujuran, yaitu ketulusan hati seorang Pegawai Negeri
Sipil dalam melaksanakan tugas dan kemampuan untuk melaksanakan wewenang yang diberikan kepadanya;

6) Kerjasama, yaitu kemampuan seorang Pegawai Negeri Sipil untuk bekerja bersama-sama dengan orang lain dalam menyelesaikan sesuatu tugas yang ditentukan, sehingga mencapai dayaguna dan hasilguna yang sebesarbesarnya;

7) Prakarsa, merupakan kemampuan seorang Pegawai Negeri Sipil untuk mengambil keputusan, langkah-langkah, atau melaksanakan sesuatu tindakan yang diperlukan dalam melaksanakan tugas pokok tanpa menunggu perintah dari atasan; dan

8) Kepemimpinan, yaitu kemampuan seorang Pegawai Negeri Sipil untuk meyakinkan orang lain sehingga dapat dikerahkan secara maksimal untuk melaksanakan tugas pokok.

\section{Kerangka Berpikir}

Menurut Sugiyono (2014) kerangka berpikir adalah sintesa yang mencerminkan keterkaitan antara variabel yang diteliti dan merupakan tuntunan untuk memecahkan masalah penelitian serta merumuskan hipotesis penelitian yang berbentuk bagan alur yang dilengkapi penjelasan kualitatif.

Berdasarkan uraian di atas dapat disimpulkan kerangka berfikir penelitian dapat digambarkan sebagai berikut: 


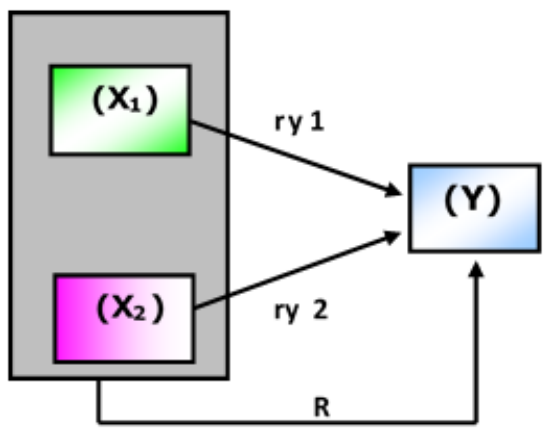

\section{Gambar Kerangka Berfikir} Penelitian

Keterangan :

ry $1=$ Pengaruh parsial antara Kompetensi Pedagogik terhadap Kinerja Guru SMP Negeri 17 Kota Tangerang Selatan

ry 2 = Pengaruh parsial antara Motivasi Kerja terhadap Kinerja Guru SMP Negeri 17 Kota Tangerang Selatan

$\mathrm{R}=$ Pengaruh simultan antara Kompetensi Pedagogik dan Motivasi Kerja terhadap Kinerja Guru SMP Negeri 17 Kota Tangerang Selatan

\section{E. Hipotesis Penelitian}

Menurut Sugiyono (2016) hipotesis merupakan jawaban sementara terhadap rumusan masalah. Karena sifatnya masih sementara, maka perlu dibuktikan kebenarannya melalui data empirik yang terkumpul.

Adapun Hipotesis yang penulis ajukan adalah sebagai berikut:

$\mathrm{HO}_{1}$ : Diduga tidak terdapat pengaruh signifikan antara kompetensi pedagogik terhadap kinerja guru di SMP Negeri $17 \quad$ Kota Tangerang Selatan.

$\mathrm{Ha}_{1}$ : Diduga terdapat pengaruh signifikan antara kompetensi pedagogik terhadap kinerja guru di SMP Negeri 17 Kota Tangerang Selatan.

$\mathrm{HO}_{2}$ : Diduga tidak terdapat pengaruh signifikan antara motivasi kerja terhadap kinerja guru di SMP Negeri 17 Kota Tangerang Selatan.

$\mathrm{Ha}_{2}$ : Diduga terdapat pengaruh signifikan antara motivasi kerja terhadap kinerja guru di SMP Negeri $17 \quad$ Kota Tangerang Selatan.

$\mathrm{HO}_{3}$ : Diduga tidak terdapat pengaruh signifikan secara bersama-sama antara kompetensi pedagogik dan motivasi kerja guru terhadap kinerja guru di SMP Negeri $17 \quad$ Kota Tangerang Selatan.

$\mathrm{Ha}_{3}$ : Diduga terdapat terdapat pengaruh signifikan secara bersama-sama antara kompetensi pedagogik dan motivasi kerja guru terhadap kinerja guru di SMP Negeri $17 \quad$ Kota Tangerang Selatan.

\section{METODOLOGI PENELITIAN}

A. Tempat dan Waktu Penelitian

1. Tempat Penelitian 
Tempat penelitian ini dilakukan di SMP Negeri 17 Kota Tangerang Selatan, Komplek Pamulang Permai 1, Kota Tangerang Selatan.

2. Waktu Penelitian

Waktu yang digunakan untuk penelitian ini adalah dari Nopember 2010 hingga Desember 2010.

\section{B. Populasi dan Sampel}

Menurut Mohamad Ali (1985: 54) menyatakan populasi target adalah jumlah obyek yang akan diteliti.Dengan demikian yang menjadi populasi dalam penelitian ini adalah guru-guru pada SMP Negeri 17 Kota Tangerang Selatan Provinsi Banten.

Sampel adalah sebagian dari jumlah dan karakteristik yang dimiliki oleh populasi tersebut. Menurut Suharsimi Arikunto (1983: 107), “Apabila subyek penelitian kurang dari 100, digunakan semua subyek sekaligus sehingga penelitiannya merupakan penelitian populasi. Jika jumlah subyek besar maka diambil $10-15 \%$, atau $20-25 \%$ atau lebih".

Oleh karena populasi dalam penelitian ini hanya berjumlah 32 dan kurang dari 100, maka dalam penelitian ini menggunakan penelitian populasi.

\section{Metode Pengumpulan data}

Data dalam penelitian ini dikumpulkan dari berbagai sumber data. Menurut Suharsimi Arikunto yang dimaksud dengan sumber data dalam penelitian adalah sumber dimana data diperoleh. Untuk memperoleh data yang lengkap dalam obyek penelitian ini, sumber data yang dapat digunakan oleh penulis meliputi:

\section{Data Primer}

Sumber data primer dalam penelitian ini diperoleh melalui penyebaran

kuesioner/angket tentang kompetensi pedagogik, motivasi kerja guru. Data kinerja guru diperoleh dari rekap laporan penilaian DP3 guru SMPN 17 Kota Tangerang Selatan Provinsi Banten bulan Desember 2010.

\section{Data Sekunder}

Data sekunder merupakan data yang diperoleh atau digali dari buku-buku atau literatur yang ada kaitannya dengan permasalahan yang akan dibahas dalam penelitian. Pendekatan yang dilakuan dalam pengumpulan data dilakukan dengan cara:

\section{a. Riset Kepustakaan} (Library Research)

Yaitu dengan
membaca literatur dan referensi yang berhubungan dengan permasalahan yang penulis diteliti.

\section{b. Riset Lapangan (Field} Research)

Pendekatan ini dilaksanakan dengan mengadakan pengamatan langsung di lapangan, sehingga diperoleh data-data yang diperlukan sebagai bahan penyusunan Penelitian ini.

\section{Teknik Analisis Data}

1. Uji Instrumen 
$\begin{array}{lr}\text { Pengujian } & \text { disini } \\ \text { dilakukan pada } & \text { data hasil } \\ \text { pengembalian } & \text { kuesioner }\end{array}$

Kompetensi Pedagogik (X1) dan Motivasi Kerja Guru (X2) serta Data Penilaian Kerja Guru - DP3 (Y) SMPN 17 Kota Tangerang Selatan bulan desember 2010. Pada data yang diperoleh dilakukan perbandingan hasil perhitungan koefisien korelasi product moment Pearson ( $\mathrm{r}_{\text {hitung }}$ ) dengan tetapan koefisien korelasi produk moment Pearson $\left(\mathrm{r}_{\text {tabel }}\right)$ dengan kriteria: 1). Jika chronbatch Alpha > 0,30 , maka instrumen valid,

2). Jika chronbatch Alpha < 0,30 , maka instrumen tidak valid

\section{b. Pengujian Reliabilitas}

Uji Reliabilitas terhadap Variabel Bebas $\mathrm{X}_{1}$, Varibel Bebas $\mathrm{X}_{2}$, dan Variabel Terikat Y. Reliabilitas menunjukkan sejauh mana suatu pengukuran dapat menghasilkan hasil yang stabil bila dilakukan pengukuran ulang kepada subyek yang sama. Tingkat reliabilitas koefisien korelasi dilakukan dengan membandingkan nilai koefisien korelasi hitung $\left(\mathrm{r}_{\mathrm{h}}\right)$ dibandingkan dengan nilai $r_{\text {table }}$ $\left(r_{t}\right)$ Product Moment pada taraf signifikasi $5 \%$ dengan ketentuan:

1) Jika $r_{\text {Alpha }}$ positif dan $r_{\text {Alpha }}$ hitung $>\quad r_{\text {table }}$ ataupunr $r_{\text {Alpha }}$ positifmaka butir atau variabel tersebut Reliabel.

2) Jika $r_{\text {Alpha }}$ negatif dan $r_{\text {Alpha }}<$ $r_{\text {tabel }}$ ataupun $r_{\text {Alpha }}$ negatif $<$ $r_{\text {tebel }}$ maka butir atau variabel tersebut tidak Reliabel.

\section{Uji Prasyarat Analisis}

\section{a. Uji Normalitas}

Uji normalitas data pada penelitian ini menggunakan metode Kolmogorov Smirnov, dengan taraf signifikansi yang digunakan sebagai aturan untuk menerima atau menolak pengujian normalitas atau tidaknya suatu distribusi data adalah taraf signifikansi $\alpha=$ 0,05 .

Uji kenormalan dipenuhi jika hasil uji signifikansi yang diperoleh $>\alpha$, maka sampel berasal dari populasi yang berdistribusi normal.

\section{b. Uji Linearitas}

Pengujian linearitas variabel bertujuan untuk mengetahui apakah dua variabel mempunyai hubungan yang linear atau tidak secara signifikan. Dua variable dikatakan mempunyai hubungan yang linear bila siginifikansi pada deviation from linearity kurang dari 0,05 .

\section{c. Uji Homogenitas}

Pengujian homogenitas variabel bertujuan untuk menguji homogenitas varians antara kelompok skor $\mathrm{Y}$ yang dikelompokkan berdasarkan kesamaan nilai $X$. pengujian homogenitas varians ini dilakukan dengan uji Barlett.

$$
\text { Adapun kriteria }
$$

pengujian adalah dengan membandingkan taraf signifikansi yang diperoleh 
dengan taraf signifikansi uji $\alpha$ $=0,01$ atau $\alpha=, 005$. Ho diterima apabila hasil uji signifikansi lebih kecil atau sama dengan taraf signifikasi uji 0,05 atau 0,01 .

\section{Analisis Data}

\section{a. Analisis Deskripsi}

$$
\text { Analisis }
$$

dilakukan

dengan melihat frekuensi dari pilihan opsi oleh responden yang disediakan pada setiap pertanyaan kuesioner yang diberikan. Dalam penelitian ini, untuk pembobotan data, peneliti menggunakan skala pengukuran. Adapun skala pengukuran yang digunakan dalam penelitian ini adalah dengan skala Likert.

b. Analisis Verifikatif

\section{1) Analisis Korelasi}

Analisis korelasi digunakan untuk mengukur hubungan variable dependen dengan variable dependennya, baik secara parsial maupun secara simultan. Dalam hal ini adalah Kompetensi Pedagogik $\left(\mathrm{X}_{1}\right)$ dan Motivasi Kerja (X2) terhadap variabel Kinerja Guru (Y) SMPN 17 Kota Tangerang Selatan.

2) Analisis Regresi

Analisis ini dilakukan untuk mencapai tujuan penelitian, yaitu mengetahui pengaruh antara variabel dependen Kompetensi Pedagogik $\left(\mathrm{X}_{1}\right)$ dan Motivasi Kerja (X2) terhadap variabel independen Kinerja Guru
(Y) SMPN 17 Kota Tangerang Selatan.

3) Uji Hipotesis Statistik

Hipotesis statistik dilakukan untuk menguji dugaan sementara yang dirumuskan dalam hipotesis berdasarkan data empiris. Dalam penelitian ini uji hipotesis dilakukan menggunakan uji t dan uji F.

\section{HASIL PENELITIAN DAN}

\section{PEMBAHASAN}

\section{A. Uji Instrumen}

\section{Uji Validitas}

Dari pengujian 40 butir instrument Kompetensi Pedagogik (X1), terdapat 25 instrumen valid dan 15 instrumen yang tidak valid karena belum digunakan. Sehingga diperoleh 15 instrumen kuesioner yang layak diolah sebagai data penelitian.

Dan dari pengujian 40 butir instrument motivasi kerja (X2), terdapat 34 instrumen valid dan 6 instrumen yang tidak valid. Sehingga diperoleh 34 instrumen kuesioner yang layak diolah sebagai data penelitian.

Sedangkan dari pengujian 8 butir instrument penilaian kinerja guru, terdapat 7 instrumen valid dan 1 instrumen yang tidak valid karena belum digunakan. Sehingga diperoleh 7 instrumen kuesioner yang layak diolah sebagai data penelitian.

\section{Uji Reliabilitas}

Berdasar perhitungan 
dengan menggunakan menggunakan diperoleh nilai Cronbach Alfa lebih besar dari 0.60 , dengan demikian maka semua butir pernyataan pada variabel penelitian dinyatakan reliabel.

\section{B. Uji Prasyarat Analisis}

Uji prasyarat analisis diperlukan untuk mengetahui apakah analisis pengujian dapat dilanjutkan atau tidak. Minimal sebelum dilakukan uji hipotesis harus dilakukan dua uji prasysrat analisis, yaitu uji normalitas dan uji homogenitas (www.goodwell.blogspot.com/2011/11/oneway-anova-analysis.html).

Untuk prasarat uji anallisis regresi, biasanya selain dua uji prasyarat di atas, juga harus dilakukan uji linearitas.

\section{Uji Normalitas}

Dari pengujian normalitas dengan sampel untuk masing-masing variabel 32 orang pada taraf signifikansi (a) 0,05 diperoleh hasil signifikansi variabel kompetensi pedagogik $\left(\mathrm{X}_{1}\right)$ 0,872 , signifikansi motivasi kerja $\left(\mathrm{X}_{2}\right) \quad 0,800 \quad$ dan signifikansi kinerja guru 0,000. Karena nilai signifikansi $\mathrm{X}_{1}>\alpha$ dan nilai signifikansi hasil perhitungan variabel $\mathrm{X}_{2}>\alpha$ maka diperoleh kesimpulan bahwa data pada variabel kompetensi pedagogik dan variabel motivasi kerja guru berasal dari populasi yang berdistribusi normal.

Sedangkan untuk variabel kinerja guru, diperoleh signifikansi $0,000<0,05$, maka dapat disimpulan bahwa data pada variabel kinerja guru tidak berasal dari populasi terdistribusi normal.

\section{Uji Linearitas}

Berdasarkan

hasil perhitungan, diperoleh pada tabel anova signifikansi antara kinerja guru dan kompetensi pedagogik sebesar 0,028. Karena signifikansi kurang dari 0,05 maka dapat disimpulkan bahwa antara variabel kinerja guru dan variabel kompetensi pedagogik guru terdapat hubungan yang linear. Sedang antara kinerja guru dan motivasi guru diperoleh signifikansi 0,784 sehingga dapat disimpulkan bahwa antara kinerja guru dan motivasi kerja guru terdapat hubungan yang tidak linear.

\section{Uji Homogenitas}

Berdasarkan

hasil penghitungan uji homogenitas, diperoleh hasil uji homogenitas antara $\mathrm{X}_{1}$ atas $\mathrm{Y}$ sebesar 0,049. Sedangkan antara $\mathrm{X}_{2}$ atas $\mathrm{Y}$ sebesar 0,755. Hasil pengujian tersebut menunjukkan bahwa skor setiap variabel penelitian dari pengujian $\mathrm{X}_{2}$ atas $\mathrm{Y}$ belum memenuhi syarat untuk dilakukan pengujian statistik lebih lanjut, yaitu pengujian hipotesis. Jika uji prasyarat sebelum uji hipotesis tidak terpenuhi, harus dilakukan analisis Kruskal Wallis untuk dapat melakukan uji hipotesis.

\section{AnalisisKruskal Wallis}

Uji Kruskal Wallis dengan derajat kebebasan (df) $=1$ dan probabilitas 0,05 mempunyai nilai tabel Chi Kuadrat 3,8415. Dari pengujian 
Kruskal Wallis dengan SPSS versi 15 , diperoleh signifikansi $\mathrm{X}_{1}=0,314$, signifikansi $\mathrm{X}_{2}=$ 0.046, dan signifikansi $\mathrm{Y}=$ 0,329. Karena Chi Kuadrat hasil uji dari masing-masing variabel lebih kecil dari nilai tabel Chi Kuadrat, maka Ho dapat diterima dan dapat disimpulkan bahwa sampel berasal dari populasi yang sama atau variansi dari masingmasing variabel tidak terdapat perbedaan yang bermakna, sehingga pengujian hipotesis analisis selanjutnya dapat dilakukan.

\section{Analisis Data}

\section{Analisis Deskripsi Data}

Deskripsi data yang
disajikan bertujuan untuk
memberikan gambaran secara
umum mengenai penyebaran
data yang diperoleh di
lapangan. Data yang disajikan
berupa data mentah yang
diolah menggunakan teknik
statistik deskripsi. Deskripsi
tersebut berguna untuk
menjelaskan penyebaran data
menurut frekuensinya, untuk
menjelaskan kecenderungan
terbanyak, untuk menjelaskan
kecenderugan tengah, untuk
menjelaskan pola penyebaran
(maksimum-minimum), untuk
menjelaskan pola penyebaran
atau homogenitas data.

Deskripsi dari masingmasing variabel berdasarkan hasil penyebaran kuesioner kepada 32 orang guru tersebut hasilnya dapat dijelaskan di bawah ini.

\section{a. Data Variabel Kompetensi Pedagogik $\left(\mathbf{X}_{1}\right)$}

\begin{abstract}
Data dari hasil penelitian mengenai variabel bebas pertama yaitu Kompetensi Pedagogik $\left(\mathrm{X}_{1}\right)$ yang dijaring melalui penyebaran kuesioner, dengan jumlah pertanyaan sebanyak 40 butir instrumen dengan penggunaan skala pilihan jawaban skala lima (5 opsion) dan diperoleh 25 butir instrument valid sehingga variabel $\mathrm{X}_{1}$ mempunyai skor teoretik antara 25 sampai 125 , dan rentang skor empiris antara 76 sampai 115, dengan skor total 3095, rata-rata (M) 96,72 , simpangan baku (SD) 10,804, median (Me) 95,75, modus (Mo) 95, dan varians 116,725. Sebanyak $20 \quad(62,5 \%)$ responden berada pada kelompok ratarata, $7 \quad(21,875 \%)$ responden berada di atas kelompok rata-rata dan 5 $(15,625 \%)$ responden di bawah kelompok rata-rata.
\end{abstract}

\section{b. Data Variabel Motivasi}

Kerja Guru $\left(\mathbf{X}_{2}\right)$

Data dari hasil penelitian mengenai variabel bebas kedua yaitu Motivasi Kerja Pendidik $\left(\mathrm{X}_{2}\right)$ melalui penyebaran kuesioner, dengan jumlah pertanyaan sebanyak 50 butir instrumen dengan penggunaan skala pilihan jawaban skala lima (5 opsion), dan diperoleh 34 butir instrument valid. Sehingga variabel $\mathrm{X}_{2}$ mempunyai skor teoretik 
antara 34 sampai 170 dan rentang skor empiris antara 87 sampai 168, dengan skor total 4299 , rata-rata $(\mathrm{M})$ 134,34, simpangan baku (SD) 10,804, median (Me) 95,75, modus $(\mathrm{Mo})=133$, dan varians 212,555. Sebanyak $19 \quad(59,375 \%)$ responden berada pada kelompok rata-rata, 7 $(21,875 \%)$ responden berada di atas kelompok rata-rata dan $6(18,75 \%)$ responden di bawah kelompok rata-rata.

c. Data Variabel Kinerja Guru (Y)

Mengenai data dari hasil penelitian variabel terikat yaitu Kinerja Guru (Y) yang diperoleh dari penilaian DP-3 guru SMP Negeri 17 Kota Tangerang Selatan pada tahun 2010 sebanyak 7 butir instrumen penilaian. Pada penelitian ini, penilaian kinerja guru dikodekan terlebih dahulu menjadi 4 opsion, sehingga variabel $\mathrm{Y}$ mempunyai rentang skorteoretik antara 7 sampai 28 dan rentang skor empiris antara 7 sampai 26, dengan skor total 292, ratarata (M) 9,13, simpangan baku (SD) 0,937, median (Me) 7,44, modus $(\mathrm{Mo})=$ 7 , dan varians 28,113. Sebanyak $1 \quad(3,125 \%)$ responden berada pada kelompok rata-rata, 26 $(81,25 \%)$ responden berada di atas kelompok rata-rata dan $5(15,625 \%)$ responden di bawah kelompok rata-rata
2. Uji Verifikatif

a. Analisis Korelasi

1) Analisis

Korelasi Sederhana

Pengujian korelasi antar variabel penelitian menggunakan analisis bivariate correllation pada SPSS versi 15 , dan diperoleh hasil seperti dalam Tabel berikut.

Tabel Korelasi antar Variabel Penelitian

\begin{tabular}{|c|c|c|c|c|}
\hline & & $\begin{array}{c}\text { Kompet } \\
\text { ensi } \\
\text { Pedagog } \\
\text { ik Guru }\end{array}$ & $\begin{array}{c}\text { Motiv } \\
\text { asi } \\
\text { Kerja }\end{array}$ & $\begin{array}{c}\text { Kine } \\
\text { rja } \\
\text { Guru }\end{array}$ \\
\hline $\begin{array}{c}\text { Kompetensi } \\
\text { Pedagogik } \\
\text { Guru }\end{array}$ & $\begin{array}{c}\text { Pearson } \\
\text { Correlat } \\
\text { ion }\end{array}$ & 1 & .386 & .171 \\
\hline $\begin{array}{c}\text { Motivasi } \\
\text { Kerja }\end{array}$ & $\begin{array}{c}\text { Pearson } \\
\text { Correlat } \\
\text { ion }\end{array}$ & .386 & 1 & -.355 \\
\hline $\begin{array}{c}\text { Kinerja } \\
\text { Guru }\end{array}$ & $\begin{array}{c}\text { Pearson } \\
\text { Correlat } \\
\text { ion }\end{array}$ & .171 & -.355 & 1 \\
\hline
\end{tabular}

** Correlation is significant at the 0.01 level (2-tailed).

Sumber : Data diolah

Dari tabel di atas, di antara kompetensi pedagogik guru $\left(\mathrm{X}_{1}\right)$ dengan kinerja guru $(\mathrm{Y})$ terdapat $\mathrm{r}_{\text {pearson }}$ sebesar 0,171 , ini menunjukkan terdapat hubungan lemah positif antara kompetensi pedagogik guru dengan kinerja guru. Hubungan cukup kuat negatif terjadi antara motivasi kerja guru $\left(\mathrm{X}_{2}\right)$ dengan kinerja guru (Y) yang ditunjukkan oleh $r_{\text {pearson }}$ sebesar - $\quad 0,355$. Hubungan cukup kuat positif terjadi antara 
kompetensi pedagogik guru dengan motivasi kerja guru ditunjukkan oleh $\mathrm{r}_{\text {pearson }}$ sebesar 0,386 .

2) Analisis

Korelasi Ganda

Analisis korelasi ganda dipergunakan untuk mengetahui hubungan antara dua atau lebih variabel bebas $\left(\mathrm{X}_{1}\right.$, $\left.\mathrm{X}_{2}, \ldots, \mathrm{Xn}\right)$ dengan variabel terikatnya $(\mathrm{Y})$.

Hasil analisis regresi

pada output model

summary dan disajikan sebagai berikut:

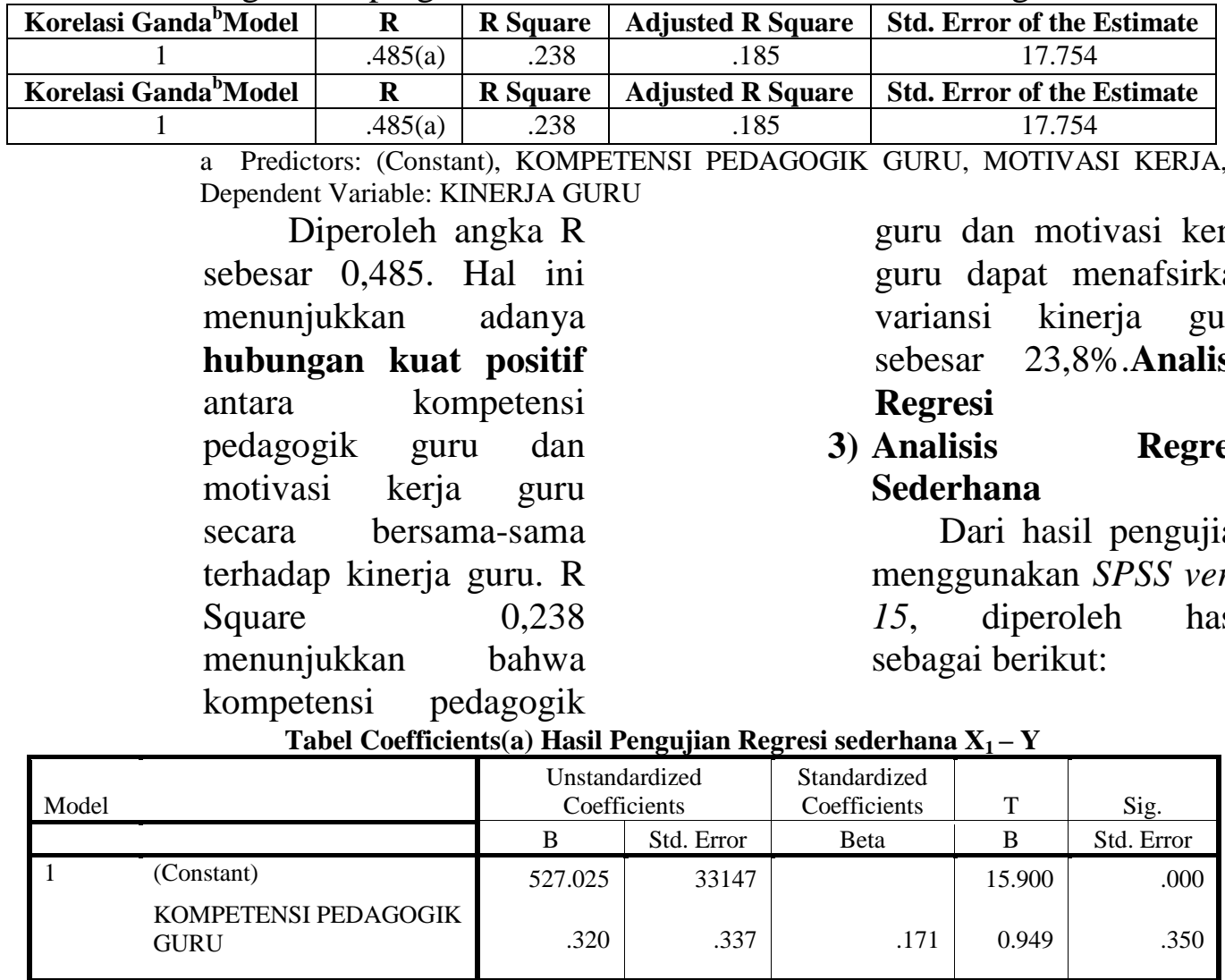

a Dependent Variable: KINERJA GURU sumber : data diolah

Berdasarkan hasil perhitungan pada tabel di atas, diperoleh bentuk persamaan regresi: $\mathrm{Y}=$ $527,052+0,320 X_{1}$

Tabel Coefficients(a) Hasil Pengujian Regresi sederhana $X_{2}-Y$

\begin{tabular}{|c|c|c|c|c|c|c|}
\hline \multirow{2}{*}{\multicolumn{2}{|c|}{ Model }} & \multicolumn{2}{|c|}{$\begin{array}{l}\text { Unstandardized } \\
\text { Coefficients }\end{array}$} & \multirow{2}{*}{$\begin{array}{c}\text { Standardized } \\
\text { Coefficients } \\
\text { Beta } \\
\end{array}$} & \multirow{2}{*}{$\begin{array}{l}\mathrm{T} \\
\mathrm{B} \\
\end{array}$} & \multirow{2}{*}{$\begin{array}{c}\text { Sig. } \\
\text { Std. Error }\end{array}$} \\
\hline & & $\mathrm{B}$ & Std. Error & & & \\
\hline \multirow[t]{2}{*}{1} & (Constant) & 639.925 & 39376 & & 16.252 & .000 \\
\hline & MOTIVASI KERJA & -.579 & .287 & -.355 & & .046 \\
\hline
\end{tabular}

a Dependent Variable: KINERJA GURU sumber : data diolah

Berdasarkan hasil perhitungan pada tabel di atas, diperoleh bentuk persamaan regresi: $\mathrm{Y}=$ $639,925-579 \mathrm{X}_{2}$

4) Analisis

Regresi 


\section{Berganda}

Analisis

berganda dimaksudkan untuk mengetahui seberapa besar pengaruh variable Kompetensi Pedagogik (X1) dan Motivasi Kerja (X2) terhadap Kinerja Guru (Y). Berdasarkan perhitungan regresi linear berganda menggunakan software SPSS versi 15 for windows, diperoleh hasil sebagai berikut:

Tabel Coefficients(a) Hasil Pengujian Regresi Berganda $X_{1}$ dan $X_{2}-Y$

\begin{tabular}{|c|c|c|c|c|c|c|}
\hline \multirow{2}{*}{\multicolumn{2}{|c|}{ Model }} & \multicolumn{2}{|c|}{ Unstandardized Coefficients } & \multirow{2}{*}{$\begin{array}{c}\text { Standardized } \\
\text { Coefficients }\end{array}$} & \multirow[b]{2}{*}{$\mathrm{t}$} & \multirow[b]{2}{*}{ Sig. } \\
\hline & & $\mathrm{B}$ & Std. Error & & & \\
\hline \multirow[t]{3}{*}{1} & (Constant) & 605.761 & 40.924 & & 14.802 & .000 \\
\hline & $\begin{array}{l}\text { KOMPETENSI } \\
\text { PEDAGOGIK GURU }\end{array}$ & .678 & .329 & .362 & 2.059 & .049 \\
\hline & MOTIVASI KERJA & -.832 & .296 & -.495 & -2.815 & .009 \\
\hline
\end{tabular}

Berdasarkan hasil perhitungan pada tabel di atas, diperoleh bentuk persamaan regresi: $\mathrm{Y}=$ $605,761+0,678 X_{1}-$ $0,832 \mathrm{X}_{2}$

5) Uji Hipotesis Statistik

Pengujian hipotesis dimaksudkan untuk menetukan apakah sebaiknya hipotesis diterima atau ditolak. Dalam pengujian ini digunakan uji t (parsial) dan uji F (Simultan).

a) Uji Hipotesis Parsial

Uji Hipotesis Parsial menggunakan uji $\mathrm{t}$ yaitu untuk menguji bagaimana pengaruh variabel bebas secara sendiri-sendiri terhadap variabel terikatnya. Hipotesis Pertama : Diduga terdapat pengaruh yang signifikan antara kompetensi pedagogik terhadap kinerja guru.

Tabel Coefficients(a) Hasil Pengujian Hipotesis Pertama

\begin{tabular}{|c|c|c|c|c|c|c|}
\hline Model & & \multicolumn{2}{|c|}{ Unstandardized Coefficients } & $\begin{array}{c}\text { Standardized } \\
\text { Coefficients } \\
\text { Beta }\end{array}$ & $\begin{array}{l}\mathrm{T} \\
\mathrm{B}\end{array}$ & $\begin{array}{c}\text { Sig. } \\
\text { Std. Error }\end{array}$ \\
\hline 1 & (Constant) & 527.025 & 33147 & & 15.900 & .000 \\
\hline & $\begin{array}{l}\text { KOMPETENSI } \\
\text { PEDAGOGIK GURU }\end{array}$ & .320 & .337 & .171 & 0.949 & .350 \\
\hline
\end{tabular}

a Dependent Variable: KINERJA GURU

sumber : data diolah

Berdasarkan hasil pengolahan data di atas, diperoleh $\rho$ value $0,350<$ 0,05 . Hipotesis pertama yang menyatakan diduga terdapat pengaruh yang signifikan antara kompetensi pedagogik terhadap kinerja guru, tidak dapat diterima.

Hipotesis kedua : Diduga terdapat pengaruh yang signifikan antara motivasi kerja dengan kinerja guru.

Tabel Coefficients(a) Hasil Pengujian Hipotesis Kedua

\begin{tabular}{|c|c|c|c|c|c|}
\hline \multirow[b]{2}{*}{ Model } & \multicolumn{2}{|c|}{ Unstandardized Coefficients } & $\begin{array}{l}\text { Standardized } \\
\text { Coefficients }\end{array}$ & $\mathrm{T}$ & Sig. \\
\hline & B & Std. Error & Beta & B & Std. Error \\
\hline
\end{tabular}




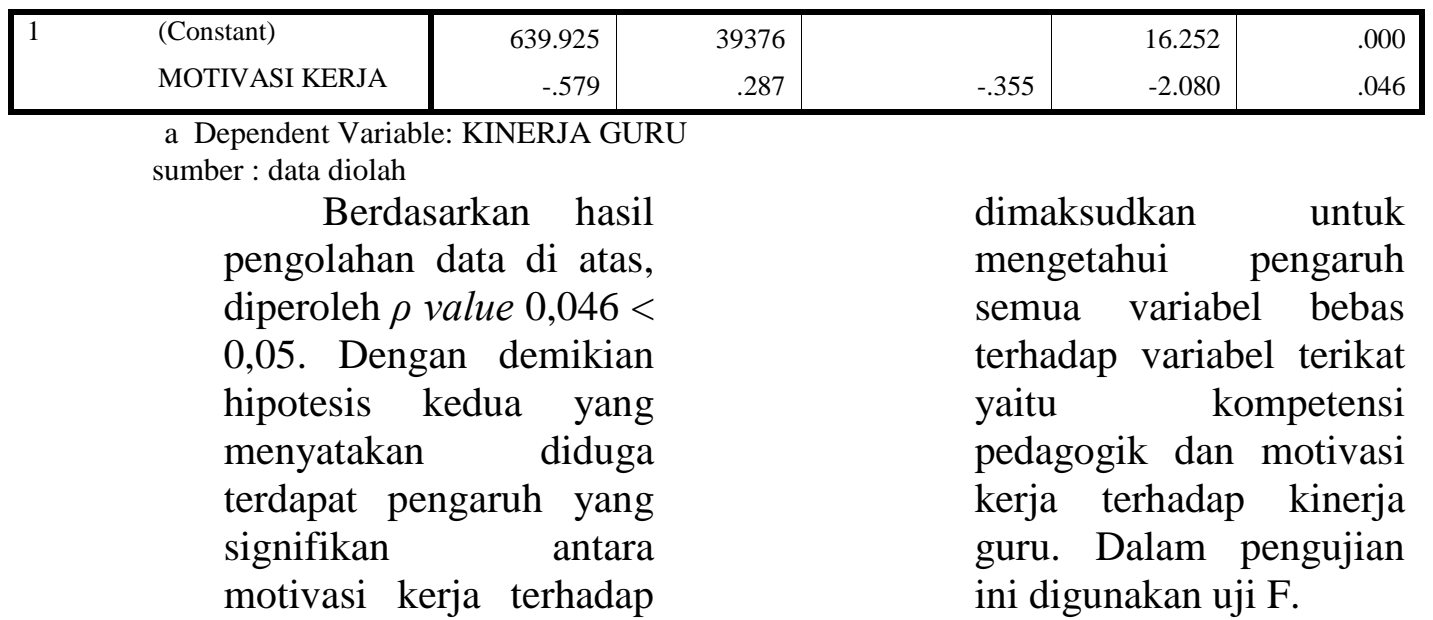

kinerja guru, dapat Hipotesis Ketiga: Diduga terdapat diterima. $\quad$ pengaruh yang signifikan antara

b) Uji Hipotesis Simultan kompetensi pedagogik (X1) dan (Uji F) motivasi kerja (X2) secara simultan terhadap kinerja guru (Y). Adapun secara simultan hasil pengujiannya sebagai berikut:

Tabel Coefficients(a) Hasil Pengujian Hipotesis Simultan

\begin{tabular}{|ll|r|r|r|r|r|}
\hline Model & & Sum of Squares & \multicolumn{1}{|c|}{ df } & Mean Square & F & Sig. \\
\hline 1 & Regression & 961.517 & 2 & 480.759 & 1.268 & \\
& Residual & 10991.483 & 29 & 379.017 & & \\
& Total & 11953.000 & 31 & & & \\
\hline
\end{tabular}

a. Dependent Variable: KINERJA GURU

b. Predictors: (Constant), MOTIVASI KERJA, KOMPETENSI PEDAGOGIK GURU sumber: Data diolah

Diperoleh $\rho$ value $0,026<$

0,05 , dengan demikian hipotesis ketiga yang menyatakan diduga terdapat pengaruh yang signifikan antara kompetensi pedagogik (X1) dan motivasi kerja (X2) secara simultan terhadap kinerja guru (Y) dapat diterima.

\section{INTERPRETASI PENELITIAN}

Sesuai dengan rumusan masalah yang yang ada dan berdasarkan analisis penelitian yang telah dilakukan, maka dari data yang telah diperoleh dapat diberikan penafsiran hasil akhir analisa sebagai berikut:

1. Antara variabel kompetensi pedagogik (X1) dan kinerja guru (Y) diperoleh persamaan regresi
$\mathrm{Y}=527,052+0,320 \mathrm{X}_{1}$. Konstanta $\mathrm{X}_{1}$ memiliki nilai positif sehingga apabila kompetensi pedagogik meningkat maka kinerja guru juga mengalami peningkatan. Analisis korelasi menunjukkan korelasi yang positif lemah sebesar 0,171 . Dari uji hipotesis diperoleh $\rho$ value $0,350<0,05$. Dengan demikian hipotesis pertama yang menyatakan diduga terdapat pengaruh yang siginifikan antara kompetensi pedagogik terhadap kinerja guru tidak dapat diterima.

2. Antara variabel motivasi kerja guru (X2) dan kinerja guru (Y) diperoleh persamaan regresi $\mathrm{Y}=$ $639,925-0,579 X_{2}$. Konstanta $X_{2}$ memiliki nilai negatif sehingga apabila motivasi kerja guru 
meningkat maka kinerja guru akan mengalami penurunan. Analisis korelasi menunjukkan korelasi yang negatif lemah sebesar $-0,355$. Dari uji hipotesis diperoleh $\rho$ value $0,046<0,05$. Dengan demikian hipotesis kedua yang menyatakan diduga terdapat pengaruh yang siginifikan antara motivasi kerja terhadap kinerja guru dapat diterima.

3. Antara variabel kompetensi pedagogik dan motivasi guru secara secara bersama-sama terhadap kinerja guru diperoleh persamaan regresi $\mathrm{Y}=605,761+$ $0,678 \mathrm{X}_{1}-0,832 \mathrm{X}_{2}$. Analisis korelasi menunjukkan korelasi yang negatif sedanag sebesar lemah sebesar 0,485. Dari uji hipotesis diperoleh $\rho$ value 0,026 $<0,05$. Dengan demikian hipotesis ketiga yang menyatakan diduga terdapat pengaruh yang siginifikan antara kompetensi pedagogik dan motivasi kerja terhadap kinerja guru dapat diterima. Konstibusi kompetensi pedagogik dan motivasi kerja dapat menafsirkan variansi kinerja guru sebesar $23,8 \%$.

Dari penafsiran di atas, hipotesis pertama penelitian ini yaitu 'diduga terdapat pengaruh yang signifikan antara kompetensi pedagogik guru terhadap kinerja guru' tidak dapat diterima (ditolak). Sedangkan hipotesis kedua penelitian ini yaitu 'diduga terdapat pengaruh yang signifikan antara motivasi kerja guru dengan kinerja guru' dapat diterima. Untuk hipotesis ketiga penelitian yaitu 'diduga terdapat pengaruh yang signifikan antara kompetensi pedagogik dan motivasi kerja guru secara bersama-sama dengan kinerja guru' dapat diterima. Beberapa dugaan yang menjadi penyebab tidak diterimanya hipotesis pertama penelitian ini antara lain :

1. Kurangnya pemahaman guru akan kompetensi pedagogik;

2. Sikap apatisme guru terhadap sistem penilaian kerja PNS yang mensyaratkan agar nilai selal naik setiap tahun tidak bersentuhan langsung dengan kompetensi pedagogik guru; atau

3. Program peningkatan keprofesian berkelanjutan (PKB) guru yang rendah, kadangkala dilakukann guru hanya sebagai syarat kenaikan pangkat saja

Yunus (2009: 8) mengatakan kompetensi pedagogik meliputi: 1) memahami peserta didik secara mendalam; 2) Merancang pembelajaran (termasuk memahami landasan pendidikan untuk kepentingan pembelajaran); 3) Melaksanakan pembelajaran; 4) Merancang dan melaksanakan evaluasi pembelajaran; 4) Mengembangkan peserta didik untuk mengaktualissasikan berbagai potensinya.

Herman (1992) menyatakan bahwa salah satu ciri penilaian kinerja adalah adanya ketergantungan terhadap pertimbangan manusia dalam menentukan skor terhadap kinerja (performance). Agar tercapai penilaian kinerja yang sesuai dengan keadaan sebenarnya (reliable), diperlukan upaya untuk meminimalkan adanya faktor penyebab perbedaan keputusan penskoran terhadap kinerja yang sama. Reliabilitas (konsistensi) dalam penskoran sangat dituntut demi keadilan. Upaya-upaya yang 
dapat dilakukan antara lain penetapan kriteria yang jelas, pemahaman yang seragam dari sejumlah penilai terhadap kriteria, proses pengukuran tidak hanya dilakukan oleh satu orang, tidak menangguhkan penilaian, serta dilakukan secara berulang terhadap pemahaman

\section{DAFTAR PUSTAKA}

Alwi, Yaser. Hubungan antara sikap terhadap perubahan, kemampuan mengelola risiko dan etos kerja sumberdaya manusia dengan kinerja aparatur dinas pendidikan daerah.

Departemen Pendidikan Nasional, 2006. Panduan pelaksanaan sertifikasi guru. Jakarta ; Departemen Pendidikan Nasional.

Depdiknas. 2006. Undang Undang Republik Indonesia Nomor 14 Tahun 2005 Tentang Guru dan Dosen. Jakarta

Depdiknas. 2003. Undang-undang No.20 Tahun 2003 tentang Sistem Pendididkan Nasional, Fokusmedia. Bandung: Departemen Pendidikan Nasional.

Departemen Pendidikan Nasional. 2002. Kepmendiknas No. 045/U/2002. Jakarta: Nasional. Departemen Pendidikan

Dewan Perwakilan Rakyat. 2005. Undang-Undang Republik
Indonesia No. 14 tahun 2005. Jakarta: DPR-RI

Dewi Gusti. 2007. Kompetensi Pedagogik.http://dewigusti.blo gspot.com/

Ferry, Nursalam, Pendidikan dalam Keperawatan,

http://books.google.co.id/books Pendidikan

+dalam+keperawatan

H.A.R. 1999. Beberapa Agenda Reformasi Pendidikan Nasional. Dalam Perspektif Abad 21. Magelang: Tera Indonesia.

Haryanto, Zeni. 2010. Menyikapi Kompetensi Pedagogik Guru dalam Rangka Menciptakan Guru Profesional.

Hasibuan, Malayu. 1999. Organisasi dan Motivasi. Jakarta :Bumi Aksara.

Hidayat, Anang. 2007. Strategi Six Sigma, Peta Pengembangan Kualitas dan Kinerja Bisnis: Jakarta: Gramedia.

Mulyasa, E. 2006. Standar kompetensi guru dan sertifikasi. Bandung: Remaja Rosdakarya.

Sujanto. Bedjo. 2009. Cara Efektif Menuju Sertifikasi Guru. Jakarta: Raih Asah Sukses.

Supranto, J. 2009.Statistik Teori dan Aplikasi. Jakarta : Penerbit Erlangga. 